\title{
Nutrition education positively influenced the use of food labels on pre- packaged foods and purchase decision among young people in Obafemi Awolowo University Community, Nigeria
}

\author{
Olumakaiye*, Motunrayo Funke, Popoola Bolanle Rachael and Oyewale, Boluwatife \\ Dept. of Family, Nutrition and Consumer Sciences, Faculty of Agriculture, Obafemi Awolowo \\ University, Ile-Ife. \\ *Email: mfolumakaiye@ gmail.com, *+2348034021395
}

\begin{abstract}
Rate at which young people consume Pre-Packaged Food (PPF) products is on the increase in Obafemi Awolowo University Community, Nigeria. This study was conducted to evaluate the impact of nutrition education on the use of food labels on PPF and purchase decision among young people in the Community. Data were collected using questionnaire before and after intervention. Two thousand students participated in the nutrition education intervention programme, while only $10 \%$ of the participants were interviewed before and after the programme. Information on demographic characteristics, awareness and use of Pre-Packaged Food Labels (PPFL) was obtained. Data were analyzed using both descriptive and inferential statistics. Data showed that mean age of the participants was $22.12 \pm 2.9$ years and $64.5 \%$ were female. Majority $(80.0 \%)$ were aware of PPFL while 27\% were rated high in awareness of the content of PPFL. Specifically $36.9 \%$ read nutrition information on the label and vitamins and minerals were the most sought information (31.0\%) while sodium was the least (4.0\%). More than half indicated that they read labels before purchase of PPF and $47.5 \%$ claimed PPFL influenced their purchase decision. Nutrition information on the label ranked second after price among the determinants to purchase a PPF product. There was no significant relationship between level of awareness and purchase decision before the nutrition education intervention $(\mathrm{p}=0.208)$ while significant relationship existed after intervention $(\mathrm{p}=0.003)$. After the intervention, females were four times more likely to use food labels in purchase decision than males $(\mathrm{OR}=4.34,95 \%$ CI $(0.62-2.75)$, likewise, older participants were thrice more likely to use food labels in purchase decision $(\mathrm{OR}=3.05,95 \%$ $\mathrm{CI}=1.49-2.64)$ than the younger ones. Nutrition education positively influenced the use of PPFL on purchase decision of PPF products in the University community.
\end{abstract}

Keywords: Pre-packed foods, Food label, Nutritional information, Nutrition education

Paper cited: Olumakaiye; M.F., Rachael, P.B. and Boluwatife, O. (2019). Nutrition education positively influenced the use of food labels on pre-packaged foods and purchase decision among young people in Obafemi Awolowo University Community, Nigeria. South Asian Journal of Food Technology and Environment, 5(1): 797-806.

\section{Introduction}

Consumers have become increasingly concerned about their health and general wellbeing since natural food is increasingly being replaced with processed foods. To make a food product unique and distinctive, firms spend more money and time on packaging more than advertisement because packaging is mostly the utmost distinguished marketing element (Krueger and Dickson, 1994). According to Héroux et al., (1988) and Osei et al., (2012), marketers as well as manufacturers spend considerable time and substantial amount of money on packaging products in a manner that will attract consumer's attention and enhance the product 
consumption. In addition, Oghojafor et al., (2012) found that product information serves to create awareness and product knowledge; simplifies purchases in the market place; helps consumers to drop many brands from consideration, and equally helps consumers to make informed choice.

Food labels have now become a popular policy tool, they are found to be very important public health tools that are used to promote adequate diet; and hence enhance public health and wellbeing. Food label is any tag, brand, mark, pictorial or any descriptive matter written, printed, stenciled, marked, embossed or impressed on, or attached to a container of food or displayed near food for the purpose of promoting its sale. The information may include name of the food, ingredients used in its manufacture, nutritional composition, manufacture and expiry dates, recommended storage conditions, instructions for use etc. This information assists consumers to better understand the nutritional value of food and enables them to compare with similar food products and to make healthy informed food ( $\mathrm{Al}$ - Tamimi et al., 2004).

Nutritional composition is a major component of PPFL, which is referred to as Nutritional labeling. It is the profiling of a product's content of nutrients including protein, fat, carbohydrates and vitamins and energy value. Studies on nutrition labeling has been conducted in some countries; South Africa (Sunelle et al., (2010), Australia and New Zealand (Donna-Peterson et al., 2001), Lesotho (Mahgoub et al., 2007), Bultimore and Chicago (Borra, 2006), and UK (Grunert and Wills, 2007). Other studies by (Drichoutis et al., 2008; Mhurchu and Gorton, 2007; Feunekes et al., 2008) showed nutrition labels as one of the major instruments in helping people make better food purchase decisions and adopt healthier eating patterns.

Globally, developed countries have developed mandatory nutrition labelling, while developing countries especially Africa have voluntary nutrition labelling policy or none at all (Fig.1).

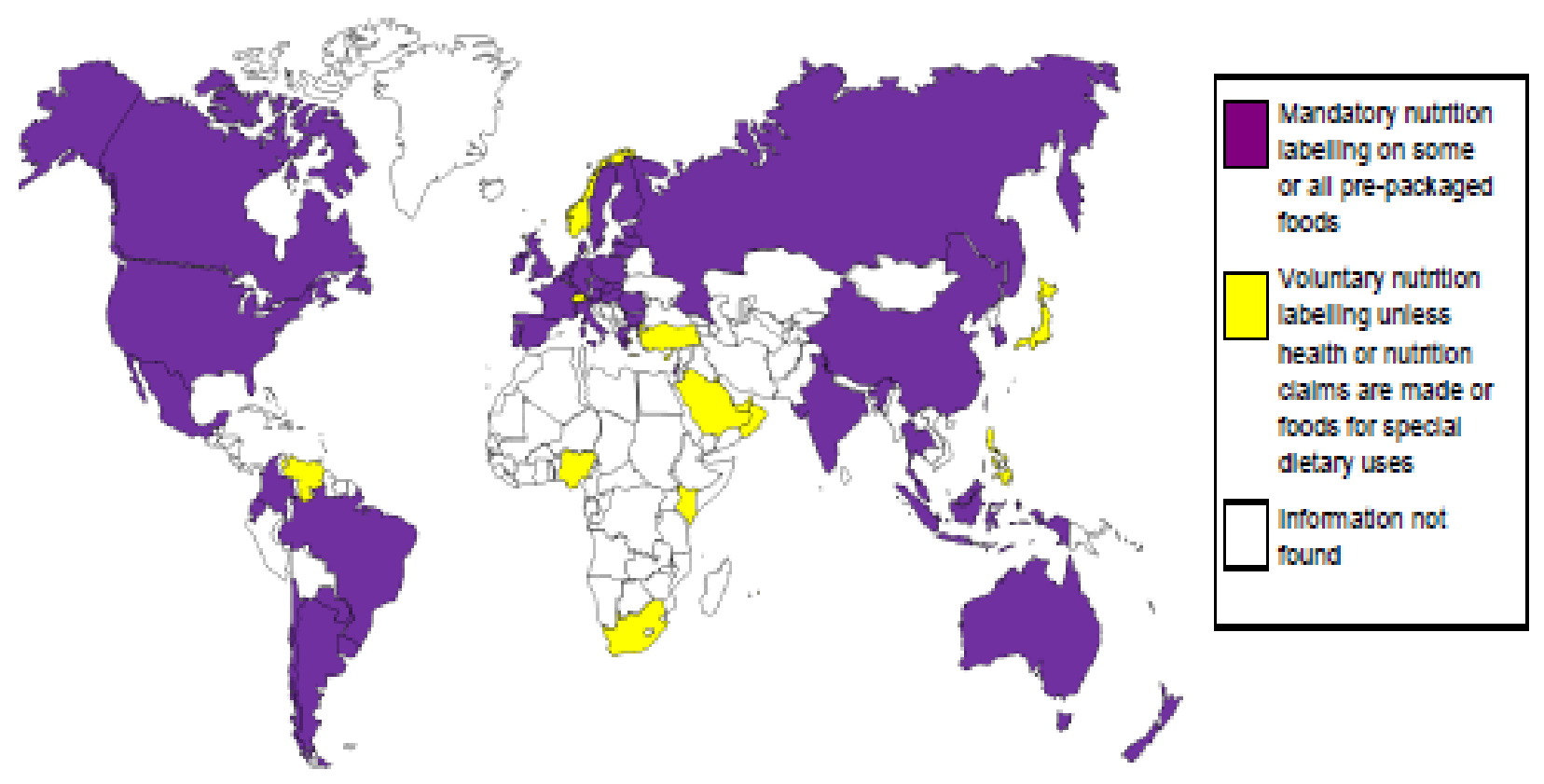

Fig. 1: Global Update on Nutrition Labelling, 2014 
In Nigeria, the National Agency for Food and Drug Administration and Control (NAFDAC) is the regulatory body responsible for the regulation and control of food product manufacturing, importation, exportation, advertisement, sale and distribution in Nigeria. NAFDAC regulations require food labeling to be informative and accurate and not fraudulent or misleading.

The practice of reading and using food labeling information in purchasing PPF is very important. Unfortunately, in most of our communities, people are not used to reading food labels. This often leads to the purchase of expired packaged foods, purchase of large quantities of foods on sale while having very short shelf life or very near expiry dates as well as purchase of foods with ingredients that one is allergic to or need to avoid due to health challenge or religious beliefs. Therefore this study aimed at investigating the awareness and use of PPFL and the influence on purchase decision among young people in Obafemi Awolowo University Community.

\section{Materials and Methods}

Study area: The survey was conducted in Obafemi Awolowo University which is a comprehensive public institution established in 1962 as the university of Ife. The university is situated on a vast expense of land totaling 11,861 hectares in Ile-Ife, Osun state southwest of Nigeria. The university comprises the central campus, the students' residential area, the staff quarters and a Teaching and Research Farm. The central campus comprises the academic, administrative unit and service centers. The students' residential areas are made up of 10 undergraduates' hostels and a postgraduate hall of residence, many shops and restaurants are located there. The university has 13 faculties and 2 colleges, the postgraduate college and the college of health sciences; it has 82 departments with about 35000 total numbers of students.

Study design: The study design used was analytical using descriptive and survey design. The design was selected because it allowed analysis of factors influencing the use of food label information in purchasing pre-packaged foods.

Sample size /procedure: The respondents for the study were non-science students, who purchased and used PPF bought from the food retail centers located in and out of the school campus. Random sampling was used to select 200 out of about 2,000 students who registered and did a special elective course on Agriculture with nutrition component.

Research instrument and data collection: The instrument used in the collection of data was a structured questionnaire. Questionnaire containing both open ended and close ended questions was used to collect information on social demographic characteristics of respondents and awareness of food label information and use of food labels before and after the lectures.

Data analysis: Data were analyzed using descriptive statistics such as frequency, percentages, means and standard deviations and inferential statistics like correlation analysis and logistic regression. Significant value was taken at $\mathrm{p} \leq 0.05$. Data were entered into a computer database using SPSS VERSION 20 computer software.

\section{Results and Discussion}

Table 1 revealed that there were more female $(64.5 \%)$ than male, about $13.5 \%$ were adolescents ( $\leq 19$ years) and majority $(76.5 \%)$ fell within the age range of 20-25years with mean age of $22.12 \pm 2.9$ while $78.5 \%$ and $95.0 \%$ lived in school hostels and were single respectively.

Data in Table 2 showed that $80 \%$ of the respondents were aware of food labels on prepackaged foods and most commonly sought information was expiry date $(32.0 \%)$ and least sought was instruction for use $(4.5 \%)$. Majority $(74.5 \%)$ of the students agreed that information on food label is very important.

Out of those who were aware of food labels on PPF, $88.0 \%$ claimed they did read and $39.8 \%$ indicated that they always did. Some were motivated to read food label out of 
curiosity about new product $(30.8 \%)$ while only $36.9 \%$ read for nutrient composition information. One of the reasons why students did not always read the labels is the technicality of the terminology used which was indicated by half of the students (Table 3), however $54.4 \%$ indicated that they did read before purchase of any PPF products.

Table 1: Demographic characteristics of respondents

\begin{tabular}{|c|c|c|}
\hline Variables & No & Percent \\
\hline Male & 71 & 35.5 \\
Female & 129 & 64.5 \\
Age(years) & & \\
$<19$ & 27 & 13.5 \\
$20-25$ & 153 & 76.5 \\
$26-30$ & 14 & 7.0 \\
$>30$ & 6 & 3.0 \\
Residential area & 157 & 78.5 \\
School hostels & 43 & 21.5 \\
Off campus & & \\
Marital status & 190 & 95.0 \\
Single & 10 & 5.0 \\
Married & & \\
\hline
\end{tabular}

Table 2:Pre-packaged food label information

\begin{tabular}{|l|c|c|}
\hline Variable & N & \% \\
\hline Food label awareness & 160 & 80 \\
Yes & 40 & 20 \\
No & & \\
Terms sought on Food Label & 18 & 9.0 \\
List of ingredients & 13 & 6.5 \\
Net content & 13 & 6.5 \\
Name of the manufacturer & 15 & 7.5 \\
Country of origin & 23 & 11.5 \\
Batch/lot identification & 18 & 9.0 \\
Manufacture date & 64 & 32.0 \\
Expiry date & 14 & 7.0 \\
Storage condition & 13 & 6.5 \\
Nutrition information & 9 & 4.5 \\
Instructions for use & & \\
Importance of food label information & 149 & 74.5 \\
Very important & 37 & 18.5 \\
Somewhat important & 11 & 5.5 \\
Minimally important & 3 & 1.5 \\
Not important & & \\
\hline
\end{tabular}


Table 4. Reading and understanding of the pre-packaged food label information

\begin{tabular}{|l|c|c|}
\hline Variable & No & \% \\
\hline Do you read nutritional label & 176 & 88.0 \\
Yes & 24 & 12.0 \\
No & & \\
Frequency of reading & 70 & 39.8 \\
Always & 90 & 51.1 \\
Sometimes & 16 & 9.1 \\
Rarely & & \\
Motivation for reading & 42 & 21.5 \\
fancy packaging & 60 & 30.8 \\
curiosity about a new product & 21 & 10.8 \\
product comparison & 72 & 36.9 \\
nutrients composition & 158 & 79.0 \\
Understand information provided & 42 & 21.0 \\
Yes & & 32 \\
No & 64 & 49.5 \\
Difficulties in reading and understanding label & 99 & 18.5 \\
print is too small & 37 & \\
technical terms & & 54.5 \\
overwhelmed or confused by too much & 109 & 45.5 \\
information & 91 & \\
Reading label before purchase of item & & \\
Yes & & \\
No & & \\
\hline
\end{tabular}

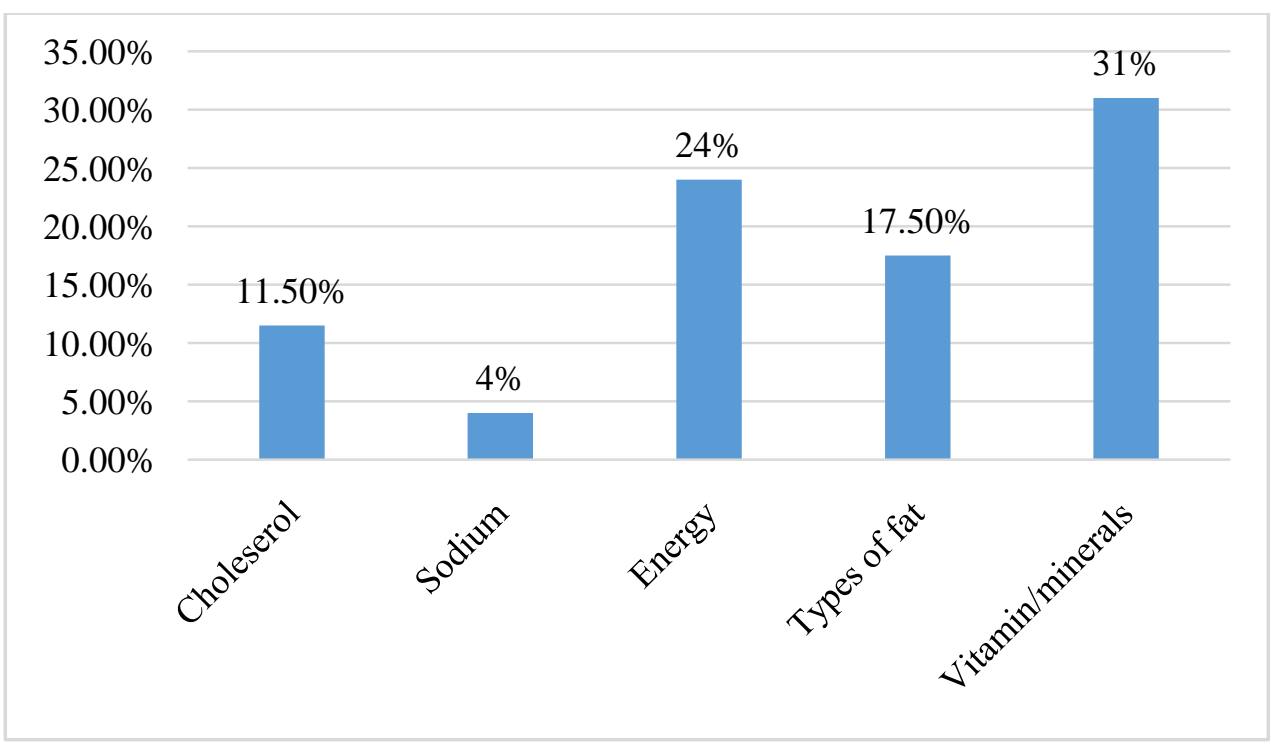

Fig.1: Nutrients commonly sought in PPFL 
Table 5: Effect of PPFL on purchase decision (Source: field survey, 2016)

\begin{tabular}{|l|c|c|}
\hline Variable & No & \% \\
\hline Effects of labels on purchase decision & & 37.0 \\
Influence the choice of brand & 74 & 47.5 \\
Influence repurchase decision & 95 & 15.5 \\
Increase desire/need to purchase & 31 & \\
Motivation to buy a particular PPF & & 36.0 \\
Price & 72 & 29.5 \\
Nutrition information & 59 & 8.5 \\
Habits & 17 & 13.5 \\
Brand name & 27 & 6.0 \\
Appearance & 12 & 6.5 \\
No reason & 13 & \\
\hline
\end{tabular}

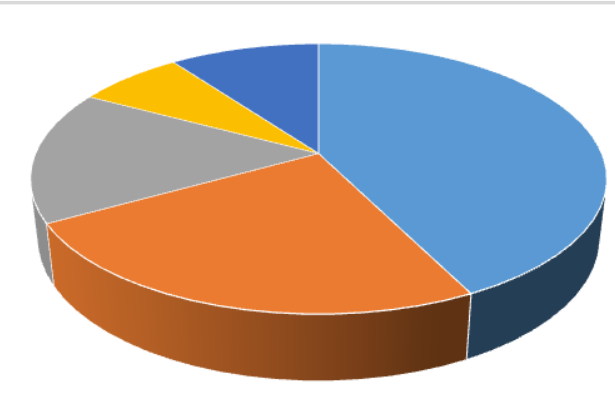

- Price $\quad$ Nutrition Information $\quad$ Brand name $\quad$ Appearance $\quad$ Habit

Fig. 2: Motivation to buy PPF

Table 6: Level of awareness before and after nutrition education intervention

\begin{tabular}{|l|l|l|l|r|}
\hline Variables & \multicolumn{2}{|c|}{ Before } & \multicolumn{2}{c|}{ After } \\
\hline level of awareness of respondents & No. (\%) & p-value & No (\%) & p-value \\
\hline $\begin{array}{l}\text { High level of awareness } \\
\text { (7-10 items) }\end{array}$ & $54(27.0)$ & & $92(46.0)$ & \\
\cline { 1 - 2 } $\begin{array}{l}\text { Middle level of awareness } \\
\text { (4-6 items) }\end{array}$ & $56(28.0)$ & 0.208 & $74(37.0)$ & $0.003 *$ \\
\cline { 1 - 2 } $\begin{array}{l}\text { Low level of awareness } \\
\text { (1-3 items) }\end{array}$ & $90(45.0)$ & $34(17.0)$ & \\
\hline $\begin{array}{l}\text { Source: field survey, 2016 } \\
\end{array}$ & $*$ Significant at $\leq 0.005$ & & \\
\hline
\end{tabular}




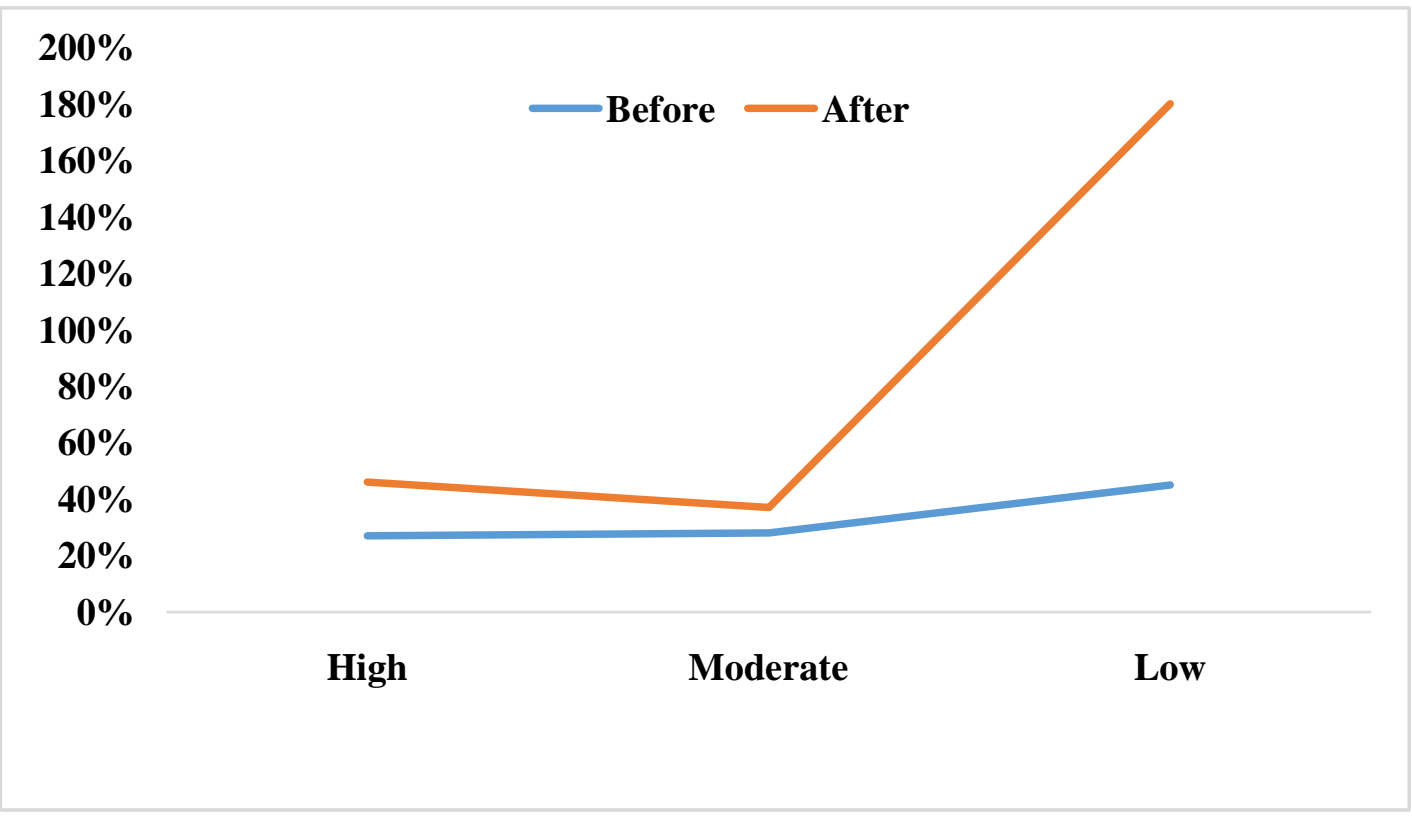

Fig. 3: Level of awareness before and after nutrition education intervention on use of PPFL

Table 7: Multivariate analysis of factors associated with use of PPFL before and after nutrition education intervention

\begin{tabular}{|c|c|c|c|c|c|}
\hline Variables & No (\%) & $\begin{array}{c}\text { OR }(95 \% \text { CI }) \\
\text { Before }\end{array}$ & p-value & $\begin{array}{c}\text { OR }(95 \% \text { CI }) \\
\text { After }\end{array}$ & p-value \\
\hline $\begin{array}{l}\text { Sex } \\
\quad \text { Male (ref) } \\
\quad \text { Female } \\
\end{array}$ & $\begin{array}{c}71(35.5) \\
129(64.5 \%)\end{array}$ & $\begin{array}{c}1.0 \\
0.87(0.41-1.52)\end{array}$ & 1.641 & $\begin{array}{c}1.0 \\
4.23(0.62-2.75)\end{array}$ & $0.001 *$ \\
\hline $\begin{array}{c}\text { Age(years) } \\
<19 \text { (ref) } \\
20-25 \\
\geq 26\end{array}$ & $\begin{array}{l}27(13.5) \\
153(76.5) \\
20(10.0) \\
\end{array}$ & $\begin{array}{c}1.0 \\
0.78(0.52-4.12) \\
0.81(0.59-1.80) \\
\end{array}$ & 0.483 & $\begin{array}{c}1.0 \\
0.92(0.57-1.81) \\
3.05(1.49-2.64) \\
\end{array}$ & $0.003 *$ \\
\hline $\begin{array}{l}\text { Religion } \\
\text { Christianity (ref) } \\
\text { Islamic } \\
\text { Traditional } \\
\end{array}$ & $\begin{array}{c}172(86.0) \\
27(13.5) \\
1(0.5) \\
\end{array}$ & $\begin{array}{c}1.0 \\
0.04(0.45-1.47) \\
0.01(0.61-1.35) \\
\end{array}$ & 0.992 & $\begin{array}{c}1.0 \\
1.02(0.57-1.81) \\
0.45(0.44-1.36) \\
\end{array}$ & 0.924 \\
\hline $\begin{array}{l}\text { Ethnic group } \\
\text { Yoruba (ref) } \\
\text { Hausa } \\
\text { Igbo } \\
\text { Others } \\
\end{array}$ & $\begin{array}{c}166(83.0) \\
7(3.5) \\
17(8.5) \\
10(5.0) \\
\end{array}$ & $\begin{array}{c}1.0 \\
0.58(0.43-0.78) \\
0.86(0.67-1.09) \\
0.71(0.11-1.52) \\
\end{array}$ & 1.762 & $\begin{array}{c}1.0 \\
1.02(0.88-1.19) \\
0.70(0.11-1.32) \\
\end{array}$ & 0.789 \\
\hline $\begin{array}{l}\text { Residential area } \\
\text { School hostels (ref) } \\
\text { Off campus } \\
\end{array}$ & $\begin{array}{c}157(78.5) \\
43(21.5)\end{array}$ & $\begin{array}{c}1.0 \\
1.03(0.58-1.79)\end{array}$ & 0.631 & $\begin{array}{c}1.0 \\
1.28(0.45-3.65)\end{array}$ & 0.076 \\
\hline $\begin{array}{l}\text { Marital status } \\
\text { Single (ref) } \\
\text { Married }\end{array}$ & $\begin{array}{c}190(95.0) \\
10(5.0)\end{array}$ & $\begin{array}{c}1.0 \\
0.77(0.53-1.55)\end{array}$ & 0.679 & $\begin{array}{c}1.0 \\
1.02(0.58-1.79)\end{array}$ & 0.09 \\
\hline
\end{tabular}


The information students sought under nutrition information on the label was also investigated; $31.0 \%$ sought for vitamins and minerals contents of the product while sodium was the least concerned (4.0\%) (Fig. 2).

Whether or not information on PPFL influenced purchase decision of any product was investigated and $47.5 \%$ reported in affirmation (Table 4). Data in Fig. 3, however showed that price was a determinant in the purchase of a product followed by nutrition information.

Data in Table 5 and Fig. 4 showed that the level of awareness on use of PPFL improved after nutrition education intervention. There was no significant relationship between level of awareness and purchase decision before intervention $\quad(p=0.208)$ while significant relationship existed after intervention $(\mathrm{p}=0.003)$. After the nutrition education intervention, the logistic regression in Table 7 indicated that older participants were thrice more likely to use food labels in purchase decision $(\mathrm{OR}=3.05,95 \% \mathrm{CI}$ $=1.49-2.64)$ than the younger ones. There was no difference before intervention.

This study was conducted to find out the use of pre-packaged food labels by university undergraduates. An intervention programme was put in place in form of a nutrition special elective course open to all students. It was found out that more females enrolled for the course compared to men. This indicated that women are more likely to seek health and nutrition related information than men, this is in agreement with studies conducted by Stefan, (2015), Bidmon and Terlutter, (2015), Pollard et al., (2015), and Regitz-Zagrosek, (2012).

Seeking nutrition information is more common among older people and individuals with chronic diseases since they check for specific nutrients, and use nutrition information on food labels more often than did individuals without such diseases.The people who have health challenges are always conscious of their food intake and this could be responsible for the awareness of information and use on food labels (Hong et al., 2014; Roberto and Khandpur 2014; Wojcicki and Heyman, 2012; Lewis et al., 2009). In this current study, since the university students were basically young people without noticeable health challenges, single and resided in university hostels, about one-fourth of the respondents scored high in the level of awareness of food labels even though majority said the use of food labels is very important but about half said they read food labels before buying any pre-packaged food.

One third of the undergraduates indicated that, search for nutritional information motivated them to read food label though they had difficulties in understanding the technical terms used at times. This was also reported in the study of Donna Peterson et al., (2001), which revealed that use of technical/scientific language on food labels situated barrier to consumers in reading and understanding labeling information when deciding to purchase prepackaged foods in Australia and New Zealand. Even though half of the respondents read label before purchasing items, many still have the habit of being loyal to brand names. Those who did not read labels gave reasons such as lack of time, too hungry/thirsty to read label, claimed that they already know the nutrition in food so, there is no need of reading, and technical terms used on label too difficult to understand.

Most common sought information on pre-packaged food labels was the expiry date. This indicated their concern about risks that might occur from consuming expired foods. The same was also reported in the South Africa (Sunelle et al., 2010), Australia and New Zealand (Donna et al., 2001) and in the UK. However, the trend was slightly different with what information consumers sought on food labels in Australia and New Zealand, whereby brand name of a pre-packaged food was highly considered followed by price and then ingredients and expiry date was the least. This could be as a result of strict code of conducts in such countries on shelved items. The general believe is that expired products are rarely found on the shelf in developed countries.

Among those that sought nutrition information, very few sought for the cholesterol, sodium and energy contents, type of fat. Vitamins/minerals contents is the most sought on pre-packaged foods labels. 
In this study, price remained the highest motivator for purchase of pre-packaged food. Label also influenced the choice of brand, repurchase decision and increase in desire/need to purchase a product. This finding is in variance with the report by Mahgoub et al., (2007) where nutrition information on food labels is reported to be the main food purchasing motivator of consumers.

There was no correlation between the level of awareness on nutritional information and its effect on their purchase decision. It shows that there is no significant relationship between level of awareness and purchase decision at 0.05 levels of significance. Study among students at UiTM Puncak Alam, Selangor, Malaysia also reported the same finding in year 2011 and 2012.

\section{Conclusion}

The undergraduates in the study area were better informed on the importance of use of food labels after the nutrition intervention. Price should not be the main reason for buying a product but nutritional components. This has implication on what they eat and effect on their health in later years. Females are the main determinant of the kind of food introduced and given to the family, therefore, they should be more informed and coupled with the fact that, a lot of women are now in paid jobs outside the home, this impacts on the time they spend in preparing food, hence, the choice of packaged food. Knowing the nutritional components of the prepackaged food should be of paramount importance.

\section{References}

Al Tamimi \& Company (2004). Standardization and Classification in the UAE. Retrieved from Center for Food safety (2006).

Bidmon, S., Terlutter, R. (2015). Gender Differences in Searching for Health Information on the Internet and the Virtual Patient-Physician Relationship in Germany: Exploratory Results on How Men and Women Differ and Why.
Journal of Medical Internet Research, 17(6): e156. doi: 10.2196/jmir.4127.

Borra, S.(2006). Consumer perspectives on food labels. American Journal of Clinical Nutrition, 83: 1235S-1235S.

Donna-Paterson, B., Rhoda-Zappelli, B., and Chalmers, Anna. (2001) Food Labelling issues consumer qualitative research: ANZFA - Australia New Zealand Food Authority.

Drichoutis, A., Lazaridis, P., Nayga, R., Kapsokefalou, M., Chryssochoidis, G. (2008). A theoretical and empirical investigation of nutritional label use. The European Journal of Health Economics, 9(3):293-304

Feunekes, G.I., Gortemaker, I.A., Willems, A.A., Lion, R., van den Kommer, M. (2008): Front-of-pack nutrition labelling: testing effectiveness of different nutrition labelling formats front-of-pack in four European countries. Appetite, 50(1): 57-70

Grunert, K.G. and Wills, J.M. (2007). A review of European research on consumer response to nutrition information on food labels. J Public Health, $\quad 15$ : 385. https://doi.org/10.1007/s10389-0070101-9

Héroux, L., Laroche, M. and McGown, K. L. (1988) Consumer Product Label Information Processing: An Experiment Involving Time Pressure and Distraction. Journal of Economic Psychology, 4: 263-272

Hong, S., Oh, S.W., Lee, C., Kwon, H., Hyeon, J. and Gwak, J. (2014). Association between Nutrition Label Use and Chronic Disease in Korean Adults: The Fourth Korea National Health and Nutrition Examination Survey 20082009. Journal of Korean Medical Science, 29(11): 1457-1463. http://doi.org/10.3346/jkms.2014.29.11. 1457

Krueger, N.J. and Dickson, P.R. (1994). How Believing in Ourselves Increases Risk Taking: Perceived Self-Efficacy and Opportunity Recognition. Decision Sciences, 25(3): 385-400. 
Lewis, J. E., Arheart, K. L., LeBlanc, W. G., Fleming, L. E., Lee, D. J., Davila, E. P., Clark, J. D. (2009). Food label use and awareness of nutritional information and recommendations among persons with chronic disease. The American Journal of Clinical Nutrition, 90(5): 1351-1357. http://doi.org/10.3945/ajcn.2009.27684

Mahgoub, S.E., Lesoli, P.P., and Gobotswang, K. (2007). Awareness and Use of nutrition information on food packages among consumers in Maseru (Lesotho). African Journal of Food Agriculture Nutrition and Development, 7(6): 1-16.

Mhurchu, C.N. and Gorton, D. (2007). Nutrition labels and claims in New Zealand and Australia: A review of use and understanding. Australian and New Zealand Journal of Public Health, 31(2): 105-112.

Oghojafor, B.E.A., Ladipo, P.K.A. and Nwagwu, K.O. (2012). An empirical determination of consumers' reaction to nutritional labeling of pre-packaged food products in Lagos, Nigeria. International Journal of Development and Sustainability, 1 (2): 171-185.

Osei-Mensah, J., Rose, L. D. and Aidoo, R. (2012) Consumers Use and Understanding of Food Label Information and Effect on their Purchasing Decision in Ghana; a Case Study of Kumasi Metropolis. Asian Journal of Agriculture and Rural Development, 2(3): 351-365.

Pollard, C.M., Pulker, C.E., Meng, X., Kerr, D.A., and Scott, J.A. (2015). Who Uses the Internet as a Source of Nutrition and Dietary Information? An Australian Population Perspective. Journal of Medical Internet Research, 17(8): e209. http://doi.org/10.2196/jmir.4548.

Regitz-Zagrosek, V. (2012). Sex and gender differences in health: Science \& Society Series on Sex and Science. EMBO Reports, 13(7): 596-603. http://doi.org/10.1038/embor.2012.87

Roberto, C.A., and Khandpur, N. (2014). Improving the design of nutrition labels to promote healthier food choices and reasonable portion sizes. International
Journal of Obesity 38 (Suppl 1): S25S33. http://doi.org/10.1038/ijo.2014.86

Stefan, Ek. (2015). Gender differences in health information behaviour: a Finnish population-based survey. Health Promotion International, 30(3-1): 736745. https://doi.org/10.1093/heapro/dat063.

Sunelle, J.A., Beer, Hanli-de and Larney, M. (2010) Adult consumers understanding and use of information on food labels. A study among consumers living in the Potchefstroom and Klerksdrorp regions, South Africa. Available at http://www. foreignpolicybulletinmonitor.com/.../dis play Fulltext?

Wojcicki, J.M., and Heyman, M.B. (2012). Adolescent nutritional awareness and use of food labels: Results from the national nutrition health and examination survey. $B M C$ Pediatrics, 12: 55. http://doi.org/10.1186/1471-2431-12-55.

\begin{tabular}{|ll|}
\hline Received & : January, 2019 \\
Revised & : February, 2019 \\
Published & : June, 2019 \\
\hline
\end{tabular}

